\title{
HÖLGYEK A (HAD)TUDOMÁNYBAN - 2020/2021
}

\section{Szerzők:}

Mező Katalin (PhD)

Debreceni Egyetem

Mező Lilla Dóra

Kocka Kör

Mező Ferenc (PhD)

\section{Lektorok:}

Kelemen Lajos (PhD)

Okoskocka Kft.

Nemes Magdolna (PhD)

Debreceni Egyetem

Eszterházy Károly Katolikus Egyetem

Első szerző e-mail címe:

kata.mezo1@gmail.com

...és további két anonim lektor

\section{Absztrakt}

A „Hölgyek a tudományban - 2020/2021” a K+F Stúdió Kft. tehetséggondozó programja fiatal nők számára. A program a magyar Nemzeti Tehetség Program támogatásával valósul meg. Jelen tanulmány felvázolja ennek a programnak a kapcsolatait a hadtudományokkal és a nők katonai karrierjével.

Kulcsszavak: nő, tehetség, katonaság

Diszciplina: Pszichológia, Pedagógia, Hadtudomány

\section{Abstract}

LADIES IN (MILITARY) SCIENCE - 2020/2021

The „Ladies in Sciences - 2020/2021” is a talent development program of K+F Stúdió $\mathrm{Kft}$ for young women. This program is realized by support of the Hungarian National Talent program. The present study sketches the connections of this program to military sciences, and to the military career of women.

Keywords: woman, talent, soldiery

Discipline: Pschology, Pedagogy, Military Science

Mező Katalin, Mező Lilla Dóra és Mező Ferenc (2021): Hölgyek a (had)tudományban 2020/2021. Lélektan és hadviselés - interdiszciplináris folyóirat, III. évf. 2021/1. szám. 103108. doi: 10.35404/LH.2021.1.103 
A $\mathrm{K}+\mathrm{F}$ Stúdió Kft. „Hölgyek a tudományban 2020/2021” címú tehetséggondozó programot valósít meg a Nemzeti Tehetség Program (NTP-NEER-20-0009 azonosítószámú) pályázati támogatásával.

1. ábra: a „Hölgyek a tudományban 2020/ 2021 projekt támogatói. Forrás: a Szerzők

\section{$\left.\approx\right|_{\text {Tehetség Program }} ^{\text {Nemzeti }}$}

A program keretében (többek között) megvalósult egy anyák és lányaik számára öt alkalommal megrendezésre kerülő, tehetség tanácsadás fókuszú workshop, ami során a nők matematikai és természettudományos, mérnöki, informatikai és orvostudományi pályák iránti orientációjáról is szó eset. Tekintettel a hadtudományok interdiszciplináris jellegére, látható, hogy ezzel olyan pályaorientációra is lehetôség nyílt, ami például a hadmérnöki, a kiberbiztonsági, a katonaorvosi, vagy a matematikai és természettudományos kutatások katonai alkalmazási lehetőségeit rejtő pályák iránt is felkelthetik az érdeklődést. A hadtudományhoz történő inter-, illetve multidiszciplináris kapcsolódási lehetősé- gek révén a múszaki és orvostudományok, illetve a reáliák és az információs technológiák felé nyitott nők kutatási eredményei pedig olyan innovációkat is eredményezhet, amelyek például a haditechnika terén hasznosíthatók.

Minderre azért célszerű még napjainkban is felhívni a pályaválasztás és/vagy karrierváltás előtt álló lányok, szülők figyelmét, mert a nők katonai szerepvállalása, ilyen jellegü karrierlehetősége még napjainkban sem köztudott. Noha a furor teutonicus, a germán harci düh kapcsán már Plutharkosz is írt a nők ókori csatákban játszott aktív szerepéről, mégis csak bő két évezreddel később, a II. világháború óta lett jellemző a nők nagyobb számú belépése a fegyveres erőkbe (Szabó, 2001), és még a XXI. század első éveiben sem haladta meg a nők aránya a 15\%-ot egyetlen hadseregben sem. Ugyanakkor a katonai pályát választó nők számára napjainkban adottak a lehetôségek (Hegymegi, 2017, lásd még: „Irány a sereg!" - a Magyar Honvédség Karrieroldala.

Megjegyzés: noha a katonai karrier kapcsán is törekedni kell a jogi értelemben vett nemek közötti esélyegyenlőségre, mégsem hagyható figyelmen kívül, hogy a nők és férfiak között általánosságban létezhetnek biológiai (például a terhesség és a szülés a nőkre hárul), pszichológiai (lásd: nemi sztereotípiákkal kapcsolatos vélt vagy valós hiedelmek), társadalmi elvárásokból (például: a katonanők szűkebb-tágabb szociális 
környezete, köztük párjuk, gyermekük, szüleik stb., szerepküldéseiből eredő) különbségek, melyek már akár a kiképzéstől kezdve befolyásolhatják a katonai pályán történő bevállást. A katonanők pályaszocializációjával kapcsolatban végzett kutatása során Györffy (2016) például már a kiképzés sikeressége kapcsán is talált a nemzetközi szakirodalomban nemi különbségekre is utaló változókat (1. táblázat).

1. táblázat: a kikeépzés siekersségét befolyásoló személyiségvonások, jellemzók, tényezọk. Forrás: györff, 2016, 33. o.)

\begin{tabular}{|c|c|}
\hline Ország/Kutató & $\begin{array}{c}\text { A kiképzés sikerességét befolyásoló } \\
\text { tényezố }\end{array}$ \\
\hline Davis (US Army) & $\begin{array}{l}\text { a kiképzésben jól teljesítök esetében a } \\
\text { megküzdési folyamat során változott az } \\
\text { észlelt stressz megítélése is, emellett } \\
\text { összefüggést talált a résztvevök magasabb } \\
\text { szorongásszintje, önészlelés során } \\
\text { megjelenô depressziója és ellenségessége } \\
\text { között, ami végül teljesítményromlást } \\
\text { eredményezett }\end{array}$ \\
\hline Lee (Kanadai haderö) & $\begin{array}{c}\text { a jó általános erőnlét, illetve a reziliens } \\
\text { személyiség }\end{array}$ \\
\hline Lubin, Fiedler és Whitlock (US Army) & egyén hangulati állapota \\
\hline Jackson (US Army) & észlelt stressz ( $85 \%$-os mértékben) \\
\hline Overdale (Új zéland -i haderő) & $\begin{array}{l}\text { megfelelö megküzdési képesség, melyet a } \\
\text { kiképzőknek kell erösítenie }\end{array}$ \\
\hline Patrick (Brit haderö) & $\begin{array}{l}\text { nöi férfi különbség: a nök esetében fontos a } \\
\text { kommunikáció lehetösége a kiképzökkel }\end{array}$ \\
\hline Lieberman (US Army) & $\begin{array}{c}\text { nök esetében a kognitiv teljesitmény és az } \\
\text { érzelmi stabilitás (a kiképzés esetében } \\
\text { mindkettő javul) }\end{array}$ \\
\hline Crowley (US Army) & $\begin{array}{c}\text { testi állapot, hangulat (szoros } \\
\text { összefüggésben) }\end{array}$ \\
\hline Banning (US Army) & honvágy \\
\hline Cook (US Army) & $\begin{array}{c}\text { külső kontroll esetében nagyobb a } \\
\text { sikertelenség }\end{array}$ \\
\hline Bradley (US Army) & dominancia, önbizalom és belső kontroll \\
\hline Davies (US Army) & distressz és depresszió kezelése \\
\hline Parmak (Belga haderö) & $\begin{array}{c}\text { magas struktúraigény és magas } \\
\text { élménykeresés }\end{array}$ \\
\hline Lee (kanadai haderõ) & $\begin{array}{c}\text { súlyosabb szomatikus tünetetek, magasabb } \\
\text { neuroticizmus, kisebb ügyesség és nagyobb } \\
\text { mértékủ alárendelōdés (negativan } \\
\text { befolyásoló tényezök) }\end{array}$ \\
\hline
\end{tabular}


Más oldalról: noha nem várható el, hogy minden fiatal lány katonai karriert akarjon megvalósítani, de az már lehetséges, hogy tudatosítjuk bennük azt, hogy civil tudományos kutatóként is elérhetnek akár honvédelmi hasznosításra (is) alkalmas eredményeket.

Sajátos alternatíva a nők katonai és civil/tudományos szerepvállalása között az a helyzet, amikor:

a) nem katonai tudományos kutatásaik katonai célú felhasználására (is) lehetôség nyílhat,

b) civilként végeznek katonai hasznosításra is alkalmas eredményekkel, innovációkkal, szabadalmakkal járó kutatási tevékenységet.

Mindez a civil-katonai együttmúködés sajátos, s kölcsönösen hasznos területe lehet.

A nők tudományos karrierjének, kutatásainak és innovációinak elősegítése tehát indirekt módon komoly „harci/szellemi potenciál" felszabadulásával kecsegteti a honvédelmet: igaz, nem a közvetlenül harcoló katonai állomány létszáma nőhet meg a civil kutatónők bevonásával és támogatásával, de a kutatónők munkája révén keletkezett kutatási eredmények és innovációk számottevő mértékben járulhatnak hozzá a honvédelem hatékonyságának biztosításához.

E megközelítés sajátossága, hogy valójában nem is kell, hogy katonai célú kutatásokat végezzenek azok a kutatónők, akiknek felfedezései, találmányai végül katonai célra is hasznosíthatók lehetnek. Ennek azonban az is következménye, hogy a tehet- séges kutatónők támogatása - függetlenül attól, hogy katonai karriert kívánnak-e megvalósítani vagy sem - mindenki (így az adott hölgy, a családja, a társadalom és a haderő) szempontjából hasznos tevékenység.

E gondolatmenet végére lényegében eljutottunk az ókori Kínában mintegy ezer éven át jelen lévő elv újra felelevenítéséhez: a nemzeti boldogulás alapja a csodálatos képességű (ma úgy mondjuk: tehetséges) gyermekek, fiatalok támogatása. Ehhez hozzátehetjük, hogy: beleértve természetesen a tehetséges hölgyek támogatását is!

Ebből a szempontból lehet tehát jelentős a K+F Stúdió Kft. által (az NTP-NEER20-0009 pályázat keretében) megvalósitott, a résztvevő anyák és lányaik számára ingyenesen kínált rendezvénysorozat, ami 2021. 02.13, 2021.02.20, 2021.02.27., 2021.03.05. és 2021.03.13. napokon került megrendezésre (2. ábra).

A COVID-19 vírusbetegség okozta pandémia folytán életbe léptetett korlátozó intézkedések miatt online formában megvalósuló workshopok és tanácsadói alkalmak során középiskolás és egyetemista korú hölgyek és szüleik számára egyrészt az időtakarékos tanulás, az ösztöndíj lehetőségek és a tudományos karrier témáit érintô csoportos fórumok biztosítására került sor, másrészt a résztvevők lehetőséget kaptak egyéni konzultációk folytatására is. $\mathrm{Az}$ időtakarékos tanulás kapcsán az OxIPO tanulás módszertani tréning főbb témakörei (olvasás-, jegyzetelés-, felelés-, dolgozatírási technikák, szövegértést és emlékezést segítő módszerek) kerültek 
2. ábra: részlet az, „Anya és Lánya” rendezvény plakátjából. Forrás: a Szuerzők.

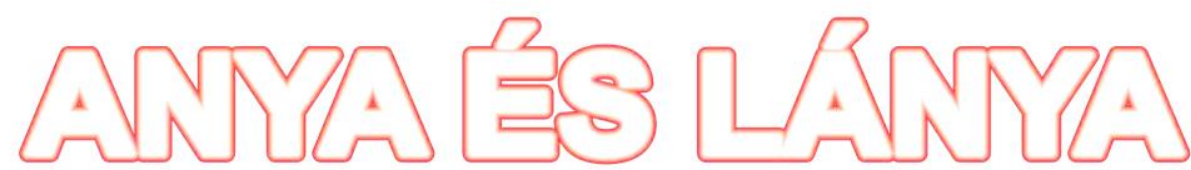

\section{INGYENES ONLINE TEHETSÉGTANÁCSADÁS}

\section{Témakörök: \\ 1) IDÖTAKERÉKOS TANULÁS \\ 2) ÖSZTÖNDÍJ LEHETÖSÉGEK \\ 3) TUDOMÁNYOS KARRIER}

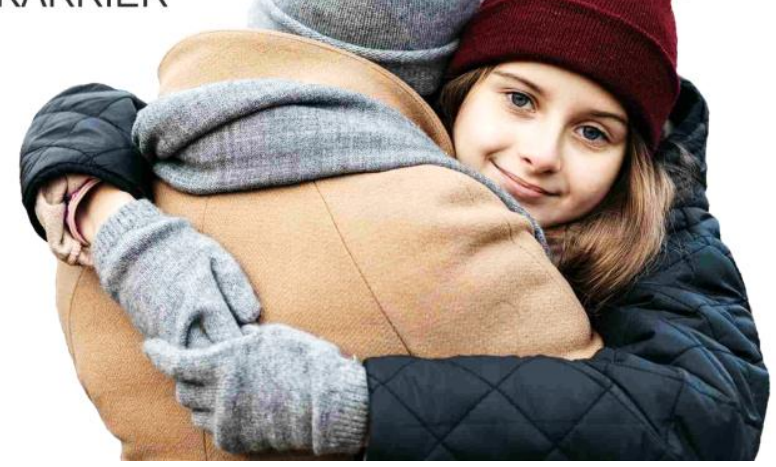

megvitatásra. Az ösztöndíj lehetőségek kapcsán azok megtalálásának, pályázati jellegzetességeiknek tárgyalására került sor különös tekintettel a Nemzeti Tehetség Program ösztöndíj-pályázataira. A tudományos karrierrel kapcsolatos egységben került bemutatásra a hazai tudományos képzés rendszere, s a lányok hagyományosan férfiasnak tekintett pályák, tudományterületek terén megvalósítható szereplehetősége - beleértve a hadtudományi karrier lehetőségét is.

\section{Irodalom}

Györffy Á. (2016): Katonanök pályaszocializációjának folyamatvizsgálata az alapkiképzéstöl a missziós feladatok vállalásáig. Doktori (PhD) értekezés. Nemzeti Közszolgálati Egyetem Hadtudományi Doktori Iskola, Budapest. Letöltés: 2021.08.09. Web: https://nkerepo.uninke.hu/xmlui/bitstream/handle/1234 56789/12367/ertekezes.pdf;jsessionid =4517E4210150D14DAFC4168ADE 3CFEAA?sequence $=1$ 
Hegymegi F. (2017): Egyenruha, bakancs és némi smink: katonanők a debreceni dandárnál. Letöltés: 2021.03.19. Web: https://www.dehir.hu/debrecen/egye nruha-bakancs-es-nemi-sminkkatonanok-a-debrecenidandarnal/2017/01/27/
Irány a Sereg! - a Magyar Honvédség Karrieroldala. Letöltés: 2021.08.09. Web: https://iranyasereg.hu Szabó M. (2001): A nők és a hadsereg. Rubiconline, 2001/6. Letöltés: 2021.03.19. Web: http://www.rubicon.hu/magyar/oldal ak/a_nok_es_a_hadsereg 